\title{
Environmental Problems and Challenges for Coastal Zone Management in the Neva Estuary (Eastern Gulf of Finland)
}

\author{
Vadim E. Panov, Alexander F. Alimov, Sergej M. Golubkov, Marina I. Orlova \\ and Irena $\mathrm{V}$. Telesh \\ Zoological Institute of the Russian Academy of Sciences, St. Petersburg, Russia
}

\begin{abstract}
Heavy nutrient and organic matter loading, resulting in enhanced primary productivity, is currently recognised as the most serious environmental problem for the Neva Estuary and adjacent parts of the eastern Gulf of Finland. The introduction of alien species is an emerging issue for the Neva Estuary and should seriously be taken into account, considering the rapid development of the shipping industry in the area. These environmental problems along with the prevailing strategy of transport-oriented development of the coastal zone in the Neva Estuary and insufficient legislative background are the main challenges for coastal zone management in the eastern Gulf of Finland. The development of comprehensive management plans could serve as an essential step toward effective coastal zone management in the Neva Estuary and adjacent areas. Management approaches to control eutrophication in the Neva Estuary coastal zone should consider the development of filamentous algae mats and emergent macrophytes in the littoral zone as the most appropriate indicator of the ecosystem state and measure of effectiveness of management actions. Management actions should be based on the scientific knowledge of the main factors controlling the development of filamentous algae, which needs further research. The management of the introduction of alien species requires different approaches and should mainly be based on preventive actions, including ballast-water control.
\end{abstract}

\section{Introduction}

The Neva Estuary is one of the most degraded parts of the Baltic Sea, impacted by a number of human activities: discharges of large amounts of waste waters from St. Petersburg (one of the largest cities in the Baltic region having a population of 
around 5 million) and its surroundings, intensive ship traffic, development of new port facilities, commercial fishery and recreation. Historical data showed a gradual deterioration in the environmental quality in the Neva Estuary area (Alimov et al. 1996; Telesh et al. 1999), and at present, important water uses such as recreation are in serious danger due to the degradation of shallow coastal (littoral or phytobenthic) habitats and beaches (Orlova et al. 1999a). However, despite sounding ecological problems, littoral ecosystems in the estuary are generally poorly studied, and monitoring of the littoral zone is lacking. As in most countries around the Baltic Sea, national research and monitoring efforts in the Neva Estuary are concentrated on the open areas (Winberg and Gutelmakher (eds) 1987; Shishkin et al. 1989; Pitkänen and Tamminen 1995; Telesh et al. 1999), and only few special research efforts are focused on littoral habitats mainly in the Neva Bay, the easternmost freshwater part of the Neva Estuary (Belavskaya 1987; Golubkov et al. 1987a, 1987b; Alimov (ed) 1988; Korelyakova 1997).

Ecosystem state assessment, research and the development of a monitoring system that is based on reliable indicators of the ecosystem state are important elements for an effective management of large aquatic ecosystems (Reynoldson 1993; Hartig et al. 1996). The lack of reliable data on the environmental quality in the littoral zone, which are essential for appropriate coastal zone management, has recently been accepted by the Baltic scientific community. First steps have been taken towards the development of more effective monitoring programmes for the shallow coastal habitats during the last decade. The international working group "Phytobenthos Monitoring" has been established within the "Gulf of Finland Year 1996" International Program framework and developed guidelines for monitoring phytobenthic zone biodiversity in the Baltic Sea (Bäck et al. 1998). At present, the monitoring programme for coastal phytobenthic areas is established in the Baltic HELCOM monitoring programme (COMBINE).

Current scientific knowledge is still not sufficient to provide a scientific basis for effective coastal zone management in the Neva Estuary area, which is a goal of ongoing and future projects. The general objective of this paper is to present an overview of the main environmental problems in the Neva Estuary coastal zone and to identify challenges for scientific research and coastal zone management.

\section{Description of the Neva Estuary}

The Neva Estuary consists of three main parts: the Neva Bay (surface area of $400 \mathrm{~km}^{2}$ ) as well as the inner and outer estuary (surface area of 3,200 km${ }^{2}$ ), which can be separated from the open eastern Gulf of Finland (Pitkänen 1991). Since the early 1980s, the freshwater of the Neva Bay is separated from the estuary's lower brackish water reaches by a storm-surge barrier, which is still under construction (Fig. 1). The Neva Bay receives water from the Neva River, the major tributary to the Baltic Sea and a connecting waterway between Lake Ladoga and the Gulf of Finland. The catchment area of the Neva River exceeds $280,000 \mathrm{~km}^{2}$, and its wa- 
ter discharge, calculated as a mean between the years 1859 and 1988, averages $2,490 \mathrm{~m}^{3} \mathrm{~s}^{-1}$ or $78,6 \mathrm{~km}^{3} \mathrm{a}^{-1}$ (Smirnova 1997).

A detailed description of the temperature and salinity regimes in the estuary is provided by Panov et al. (1999). Waters in the estuary are generally well-mixed vertically, and the near-bottom oxygen concentration is usually relatively high (Pitkänen 1991), except for the extreme situations when an intrusion of saline waters causes a strong vertical stratification of the water column in the outer estuary; as a consequence, anoxic conditions near the bottom develop, as was observed in summer 1996 (Lyakhin et al. 1997). Hydrological features of the eastern Gulf of Finland are described by Alenius et al. (1998).

The coastal zone of the Neva Estuary includes several nature-protected areas of regional and international significance. However, it has been intensively used for recreation (specifically in the Resort District of St. Petersburg), sports, commercial fishing and different industries, including a nuclear power station as well as shipping (Fig. 1). The coastal zone of the Neva Bay and the lower Neva River is also a recipient of discharges of treated and untreated waste waters.

At present, heavy nutrient and organic matter loading, mainly from point sources in the Neva River and the upper estuary, resulting in enhanced primary productivity (eutrophication), is recognised as the most serious environmental problem for the Neva Estuary and adjacent parts of the eastern Gulf of Finland (Alimov et al. 1996; Leppänen et al. 1997). The introduction of alien species is

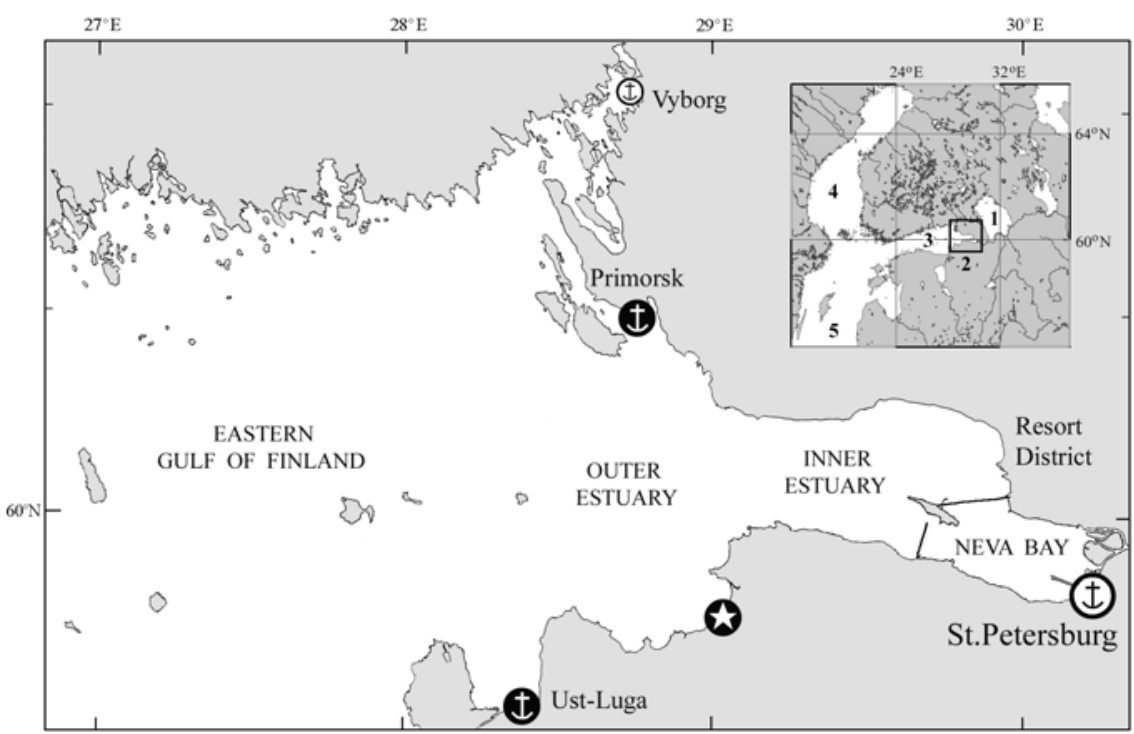

Fig. 1. The Neva Estuary and adjacent areas of the eastern Gulf of Finland. Anchors in open circles indicate main ports, anchors in filled circles indicate ports under construction, asterisk in filled circle indicate nuclear power station. Figures on the inserted map of the Baltic Sea area indicate: 1 Lake Ladoga, 2 Neva Estuary, 3 Gulf of Finland, 4 Gulf of Bothnia, 5 Baltic proper 
also an emerging issue for the Neva Estuary (Alimov et al. 1998; Orlova et al. 1999b; Panov et al. 1999) and should seriously be taken into account, considering the rapid development of the shipping industry in the area. The contamination of sediments with heavy metals and oil products is also a problem, but it relates mainly to port areas and zones of sediment accumulation in the estuary (Rybalko and Spiridonov 1999). Below, we will provide an overview of the two environmental issues mentioned above, as they are the most acute challenges for research and coastal zone management in the Neva Estuary.

\section{Effects of Eutrophication}

The increasing concentrations of nitrogen and phosphorus compounds, phytoplankton biomass and primary productivity from the western waters towards the Neva Estuary are typical features for the whole open Gulf of Finland (Leppänen et al. 1997). Primary productivity and biomass of phytoplankton in the estuary are at a highly increased level compared to the open Gulf of Finland, especially in the transition zone between the inner and outer estuary, where both physical and chemical conditions favour biological production. The Neva Estuary plays an important role in the nutrient dynamics of the whole Gulf of Finland, acting as an effective sink of phosphorus and as a source of nitrogen, which is considered as the limiting factor for algal growth in the open waters of the gulf (Pitkänen 1991; Pitkänen and Tamminen 1995). The current level of knowledge of eutrophicationrelated processes in the open waters of the Neva Estuary and the Gulf of Finland is sufficient for the establishment of appropriate mathematical models (Umnov 1996; Menshutkin (ed) 1997; Savchuk et al. 1997), which can be potentially useful for management purposes. However, in the open waters of the estuary and specifically in the Neva Bay, the development of phytoplankton (including potentially harmful blue-green algae) is generally limited by intensive hydrodynamics (Gorbatsky et al. 1997; Telesh and Nikulina 1997) and cannot be used as a reliable indicator of eutrophication (Panov et al. 1997). The construction of the storm-surge barrier in the estuary in the 1980s has changed the natural hydrodynamics in the Neva Bay, which has resulted in a significant increase of phytoplankton biomass in the western Neva Bay (Telesh and Nikulina 1997; Nikulina et al. 1999).

In the Neva Estuary, the eutrophication effects are much more obvious in the littoral zone (Panov et al. 1997; Orlova et al. 1999a), but eutrophication processes in the shallow coastal zone have not been evaluated yet. This imposes serious problems for modelling. In the Neva Bay, the enclosed freshwater part of the estuary, eutrophication resulted in the intense development of emergent macrophyte beds (mainly of the reed Phragmites australis Trin. and the bulrush Scirpus lacustris L.) along the shore, extending up to $500 \mathrm{~m}$ from the shoreline in some locations. Comprehensive studies of macrophyte beds were conducted mainly in the 1980s and 1990s. During that period, important background data on the structural 
and functional organisation of littoral communities were obtained, including a detailed description of littoral macrophyte associations (Belavskaya 1987; Korelyakova 1997), littoral zoobenthic and zooplankton communities (Golubkov et al. 1987a; Alimov (ed) 1988) and a special study on ecosystem processes in macrophyte communities with the very first recommendations for the management of such extensive macrophyte beds (Golubkov et al. 1987b). Occasional observations in the Neva Bay after 1990 have revealed a further degradation of shores due to the accumulation of decaying macrophytes in the littoral zone, most likely as a consequence of the storm-surge barrier construction and associated changes in the bay's hydrodynamics. Decaying macrophytes likely release toxic compounds or enhance the development of specific micro-organisms, which cause severe dermatitis in people coming in contact with water in the Neva Bay littoral zone.

The growth of emergent macrophytes along the exposed shores in the inner estuary is strongly limited by wave disturbance; however, filamentous green algae (mainly Cladophora glomerata (L.)) proliferate vigorously on the hard substrates in the Neva Estuary during summer. Mats of Cladophora spoil the beaches, causing serious problems for recreation in the Resort District of St. Petersburg. The exposed littoral in the inner estuary was not regularly studied until the late 1990s, except for occasional observations in the mid-1980s which first revealed the increasing development of algal mats and attributed it to severe eutrophication of the estuary (Shishkin et al. 1989). As was further discussed in the paper by Panov et al. (1997), the development of extensive macrophyte beds and Cladophora mats in the estuary during recent decades indicates heavy eutrophication, and special research efforts are needed for obtaining essential data on littoral zone functional parameters in support of coastal zone management.

The Zoological Institute of the Russian Academy of Sciences has started detailed studies of the exposed littoral zone of the inner estuary in 1998. These studies are focused on the environmental state assessment of the beaches in the St. Petersburg Resort District (Fig. 1), the development of a monitoring system for beaches and the littoral zone, and the evaluation of main factors which influence environmental quality of the Neva Estuary littoral zone, including the development of Cladophora mats. It has been shown that seasonal dynamics of Cladophora biomass in the shallow rocky littoral, along with quantitative characteristics of storm casts on the beaches (mainly decaying Cladophora mats), can be used as the most appropriate indicators of environmental quality in the coastal zone of the St. Petersburg Resort District (Orlova et al. 1999a). The volume of these casts averages several tons (in wet weight) per $100 \mathrm{~m}$ of shoreline after an ordinary storm in summer. Because mechanical removal of decaying Cladophora mats is expensive and limited to main beaches, most resort sites along the shoreline during July and August are not cleared of decaying algal storm casts and are thus not suitable for recreation. Decaying organic material on beaches is an additional source of nutrients for newly developing Cladophora mats in the littoral zone and also enhances the development of macrophyte beds on some beaches.

Essential background data on the structure and function of the Neva Estuary's coastal and littoral communities, obtained during 1982-1998, allowed to develop 
the first official recommendations for the organisation of coastal and littoral zone monitoring in the Neva Bay and eastern Gulf of Finland (Balushkina et al. 1999). These recommendations include the following main principles:

- Selection of the most representative biotopes in coastal and littoral zones (biotopes under anthropogenic stress and nature-protected habitats);

- Selection of indicator species and communities most useful for the environmental state assessment in coastal and littoral zones;

- Collection of data on biodiversity, on seasonal and on annual dynamics of the structural-functional organisation of indicator communities;

- Collection of data on hydrological and hydrochemical characteristics of biotopes and on anthropogenic impacts.

\section{Invasions of Coastal Ecosystems by Alien Species}

The introduction of alien species is a growing environmental issue world-wide. The rate of alien species introductions (invasions, biological pollution) in aquatic ecosystems around the world has accelerated significantly during the last decades, mainly due to the intensification of both shipping activity and uncontrolled release of ballast water of ships. Invasions of alien species negatively affect biological diversity, structure and functioning of aquatic ecosystems. Invasive pathogens and toxic algae are a direct threat to human health. In contrast with other anthropogenic impacts, consequences of biological pollution for natural ecosystems are mainly irreversible.

The port of St. Petersburg has a strategic position in the Baltic Sea, located at the lower Neva River at the intersection of main transoceanic (from the Atlantic Ocean) and transcontinental (from the basins of the White, Black and Caspian Seas) shipping routes. A significant part of the Neva Estuary is affected by intense ship traffic which is expected to increase more than three-fold after the completion of new ports in the outer estuary (Fig. 1).

Studies of biodiversity of the Neva Estuary coastal waters, conducted from 1995 to 2000, have shown that, with the present shipping activity, the Neva Estuary area has been invaded by several alien species with a high potential for negatively affecting local communities and ecosystems. These species include the Ponto-Caspian zebra mussel Dreissena polymorpha Pallas, the Ponto-Caspian predatory fishhook spiny waterflea Cercopagis pengoi (Ostroumov), the NorthAmerican polychaete Marenzelleria viridis (Verrill) and the Asian Chinese mitten crab Eriocheir sinensis (Milne-Edwards) (Panov et al. 1997; Alimov et al. 1998; Orlova et al. 1999b; Panov et al. 1999). Species of Siberian origin such as the Baikalian amphipod Gmelinoides fasciatus (Stebbing) and the Amur sleeper (fish) Perccottus glenii Dybows. were introduced intentionally in some lakes in the Gulf of Finland basin (Panov 1996; Alimov et al. 1998). At present, these two alien species can also be considered as a serious threat for the Neva Estuary biodiversity (Panov et al. 1999). The recent invader G. fasciatus already replaced the native 





amphipod Gammarus lacustris Sars in the Neva Bay (Panov et al. 1999) as well as in other large aquatic ecosystems in the Gulf of Finland area (Panov et al. 2000). At present, G. fasciatus has established dense populations in the littoral zone in the Neva Bay and inner estuary, where it co-exists with the alien amphipod of Ponto-Caspian origin Pontogammarus robustoides (G.O.Sars) (V. Panov unpubl.). A complete list of alien aquatic species found in the Neva Estuary area is given in Table 1.

Invasions of the Ponto-Caspian species Dreissena polymorpha and Cercopagis pengoi are likely to have the most profound effect on the Neva Estuary's coastal ecosystems. Dreissena was first found in the Neva Estuary in the late 1980s, and by 1998 , it was found well-established in littoral communities in the inner estuary, reaching densities of up to 150 individuals $\mathrm{m}^{-2}$ and biomasses of $350 \mathrm{~g} \mathrm{~m}^{-2}$ (in wet weight) (Orlova et al. 1999a, 1999b). At present, Dreissena is a dominating species (in terms of biomass) in hard-bottom littoral communities in the inner estuary at depths of $1.5-5.0 \mathrm{~m}$ and may significantly affect environmental quality in nearshore waters, specifically via recycling of nutrients and contributing to decaying organic material on beaches after storm events. A detailed study of Dreissena distribution, conducted in 2000, has revealed that, in some locations along the shore of the Resort District of St. Petersburg (Fig. 1), densities of Dreissena exceed 1,000 individuals $\mathrm{m}^{-2}$ and biomasses of $1,000 \mathrm{~g} \mathrm{~m}^{-2}$ (in wet weight). Dreissena is also an abundant species on the hard bottoms along the southern shore of the outer estuary and imposes a potential danger for functioning of water intake pipes of the nuclear power station located in this area (Fig. 1).

The Ponto-Caspian predatory crustacean Cercopagis pengoi was found in the Baltic Sea area in 1992, a likely result of the discharge of ballast water (Ojaveer and Lumberg 1995). In the same year, it was found in the open Gulf of Finland (A. Laine, pers. comm.). In 1995, C. pengoi was registered in coastal Finnish waters as a biofouler of fishing nets and in zooplankton samples from the inner Neva Estuary; since then, $C$. pengoi has become an abundant zooplankton species in both inner and outer estuary (Krylov et al. 1999; Litvinchuk et al. 2001). The $C$. pengoi population established in the Neva Estuary shows a remarkable reproductive strategy, producing a large number of resting eggs during the summer months (Panov et al. 1996; Krylov and Panov 1998). It has been suggested that this large pool of resting eggs in the Neva Estuary population has enabled $C$. pengoi to achieve fast population growth in new environments, creating an increasing risk of Cercopagis being dispersed by ships' ballast water (Panov et al. 1996).

The recent invasion of the estuary by $C$. pengoi may have important consequences for the economy. Similarly to Finland, $C$. pengoi was noted to form a paste, fouling fishing nets and trawls. Economic losses by only one fishing company, located at the northern shore of the outer estuary in Primorsk (Fig. 1), from 1996 to 2000 exceeded 50,000 USD. These losses were connected to the at least two-fold decline in fish catches in the coastal zone of the Neva Estuary due to the biofouling of fishing equipment.

As has been shown recently, the Neva Estuary can be a source of alien species for the North American Great Lakes. The predatory cladoceran Bythotrephes ced- 
erstroemi Schoedler, a native species to Lake Ladoga and the Neva Estuary, invaded the Great Lakes with the ballast water of ships returning from the Leningrad (St. Petersburg) port in the early 1980s, as suggested by Sprules et al. (1990). Recently, this hypothesis has been supported by the genetic study of Bythotrephes, confirming the existence of an eastern Baltic Sea-North American Great Lakes invasion corridor (Berg et al. 1998). In summer 1998, the Ponto-Caspian cladoceran Cercopagis pengoi was found in Lake Ontario, snagged on sportfishing lines (MacIsaac et al. 1999). Most likely, this is a question of secondary introduction from the eastern Baltic via an existing invasion corridor.

Thus, biological invasions have resulted in the development of new communities in the Neva Estuary coastal waters, with a dominance of Cordylophora caspia Pallas, Dreissena polymorpha, Potamopyrgus antipodarum (Gray) and Balanus improvisus Darwin in more saline areas and Gmelinoides fasciatus and Pontogammarus robustoides in oligosaline and freshwater locations. In pelagic communities of the estuary, the predatory cladoceran Cercopagis pengoi has been wellestablished, causing serious economic problems for coastal fisheries as biofouler of fishing nets. Recently, first attempts have been made to assess the impact of $C$. pengoi on the zooplankton community structure and productivity (Telesh et al. 2001). For benthic invertebrates in general, the most abundant populations of alien species were found in littoral habitats, and most of them are of PontoCaspian origin. These alien species are likely to play an important role in the structural and functional organisation of coastal zone ecosystems, but so far, this role has not been evaluated.

\section{Challenges for Coastal Zone Management and Directions of Future Research}

Together with the prevailing strategy of transport-oriented development of the coastal zone in the Neva Estuary and insufficient legislative background, serious existing environmental problems are the main challenges for coastal zone management in the eastern Gulf of Finland area. Efforts to reduce the loading of untreated waste waters from St. Petersburg should be complemented by activities to reduce the load of nutrients in coastal areas and to minimise the risk of alien species invasions that are associated with increasing ship traffic. A significant increase in oil pollution after the construction of new ports can also be a very serious problem. Capacities of ports in the Neva Estuary will increase manifold in the near future and may exceed 100 million tonnes per year for three main ports in St. Petersburg, Ust-Luga and Primorsk (Fig. 1) by 2010 (Rumyantsev 1999).

The absence of a controlled ballast-water release may result in catastrophic and irreversible changes in the Gulf of Finland ecosystems and develop into a most serious environmental problem of the region in the near future, taking into account the current development of new ports in the eastern Gulf of Finland and, respectively, the drastic increase in amounts of released ballast water. Examples on dis- 
astrous consequences of the introduction of alien species from other aquatic ecosystems, along with first data on economic losses for local fisheries due to Cercopagis biofouling of fishing equipment in the Neva Estuary, might force local authorities to acknowledge the problem and consider it in their decision-making. In late 1998, a first step was taken when the Baltic Special Marine Inspection (Russian Ministry of Natural Resources) started to collect and analyse available data on ballast water and ship traffic in the St. Petersburg area (Panov et al. 1999).

The development of comprehensive management plans could serve as an essential step toward effective coastal zone management in the Neva Estuary and adjacent areas. These management plans should consider all existing environmental problems and human activities in the estuary. The completion of the storm-surge barrier construction should be complemented with the development of a special environmentally-oriented plan of its exploitation, considering strong effects of the barrier on the hydrodynamics in the Neva Bay and inner part of the estuary, which may enhance eutrophication processes in the coastal zone.

Management approaches to control eutrophication in the Neva Estuary coastal zone should consider the development of Cladophora mats and emergent macrophytes in the littoral zone as the most appropriate indicator of the ecosystem state and measure of effectiveness of management actions. Management actions should be based on the scientific knowledge of the main factors controlling the development of Cladophora, which needs further research. The management of the introduction of alien species requires different approaches and should mainly be based on preventive actions, including ballast-water control. Special research efforts are needed that are directed towards environmental impact assessment and the development of a management plan to control established nuisance species, like Dreissena polymorpha and Cercopagis pengoi, and to prevent or minimise the risk of new invasions in the Neva Estuary. These research efforts should include:

- a data collection of the distribution of alien species in the eastern Gulf of Finland,

- the development of a database on alien species in the form of geographic information systems (GIS),

- an analysis of the biology and environmental requirements of target alien species,

- the assessment of environmental impact of alien species on natural communities and ecosystems,

- the assessment of socio-economic impact of alien species,

- the development of a cost-effective monitoring programme for natural biodiversity and for alien species in aquatic ecosystems,

- the risk assessment of aquatic alien species,

- the dissemination of information on the problem for the public.

The development of the inter-institutional programme Regional Biological Invasions Center (in the Internet at http://www.zin.ru/projects/invasions/) may facilitate biological invasion research, information exchange and management efforts in the Gulf of Finland area. 


\section{Acknowledgements}

Current studies of the Neva Estuary coastal zone by the Zoological Institute of the Russian Academy of Sciences are supported by the Russian Fund for Basic Research grant 00-15-97825, Russian Federal Program "Biodiversity", INTAS project No 99-674, Finnish Ministry of Environment and Maj and Tor Nessling Foundation. The authors are grateful to A. Laine (Finnish Environmental Institute) and the anonymous reviewer for valuable comments on the manuscript.

\section{References}

Alenius P, Myrberg K, Nekrasov A. (1998) Physical oceanography of the Gulf of Finland: a review. Bor Environ Res 3, pp 97-125

Alimov AF (ed) (1988): Communities of Freshwater Invertebrates in the Macrophyte Beds. Proc Zool Inst, 186, Leningrad, p 198 (in Russian)

Alimov AF, Golubkov SM, Panov VE (1996) Features of functioning and management strategy for the Neva Estuary ecosystems. In: Alimov AF and Frolov AK (eds) Ecological State of Aquatic Ecosystems in the Neva River Basin, St. Petersburg, pp 187203 (in Russian)

Alimov AF, Panov VE, Krylov PI, Telesh IV, Bychenkov DE, Zimin VL, Maximov AA, Filatova LA (1998) The problem of anthropogenic introductions of non-indigenous organisms in the Gulf of Finland basin. In: Frolov A.K. (ed) Ecological Situation in St.Petersburg and Leningrad Region in 1997. Analytic Review, St. Petersburg, pp 243248 (in Russian)

Bäck S, Ekebom J, Johansson C, Kangas P, Kautsky H, Krause-Jensen D, Mäkinen A, Nielsen K (1998) Operative Methods for Mapping and Monitoring Phytobenthic Zone Biodiversity in the Baltic Sea. II report of the PHYTOBIOS project. TemaNord 1998:568, p 72

Balushkina EV, Orlova MI, Panov VE, Umnov AA (1999) Hydrobiological monitoring of water systems of St. Petersburg and Leningrad Region. In: State Report on Environment Assessment of St. Petersburg and Leningrad Region in 1998, 2, St. Petersburg, pp 85-98 (in Russian)

Belavskaya AP (1987) Characteristics of nearshore plants. In: Winberg GG, Gutelmakher BL (eds) The Neva Bay: Hydrobiological Investigations, Nauka, Leningrad, pp 66-69 (in Russian)

Berg DJ, Garton DW, MacIsaac HJ, Panov VE (1998) Bythotrephes cederstroemi in the Great Lakes: genetic identification of a European source population and erosion of founder effects. Abstracts of the SIL XXVII Congress, August 8-14, 1998, Dublin, Ireland, pp 206

Golubkov SM, Panov VE, Pavlov AM, Petuhov VA (1987a) Littoral communities of zoobenthos. In: Winberg GG, Gutelmakher BL (eds), The Neva Bay: Hydrobiological Investigations, Nauka, Leningrad, pp 164-170 (in Russian)

Golubkov SM, Umnova LP, Anokhina LE, Panov VE (1987b) Processes of production and decomposition in the littoral macrophytes. In: Winberg GG, Gutelmakher BL (eds) 
The Neva Bay: Hydrobiological Investigations, Nauka, Leningrad, pp 70-75 (in Russian)

Gorbatsky V, Ivanov G, Ivanov D, Litvin A (1997) Hydrodynamic processes and diffusion of phytoplankton in the east part of the Gulf of Finland. In: Sarkkula J (ed) Proceedings of the Final Seminar of the Gulf of Finland Year 1996, Helsinki, pp 341-346

Hartig JH, Thomas RL, Iwachewski E (1996) Lessons from practical application of an ecosystem approach in management of the Laurentian Great Lakes. In Lakes and Reservoirs: Research and Management 2, pp 137-145

Korelyakova IL (1997): Higher Aquatic Plants of Eastern Gulf of Finland. GosNIORKH, St.Petersburg, p 158 (in Russian)

Krylov PI, Panov VE (1998) Resting eggs in the life cycle of Cercopagis pengoi, a recent invader of the Baltic Sea. Arch. Hydrobiol Spec Issues Advanc Limnol 52, pp 383-392

Krylov PI, Bychenkov DE, Panov VE, Rodionova NV, Telesh IV (1999) Distribution and seasonal dynamics of the Ponto-Caspian invader Cercopagis pengoi (Crustacea, Cladocera) in the Neva Estuary (Gulf of Finland). Hydrobiologia 393, pp 227-232

Kudersky LA (1996) State of fish resources in Lake Ladoga, Neva River and eastern Gulf of Finland. In: Alimov AF, Frolov AK (eds) Ecological State of Aquatic Ecosystems in the Neva River Basin, St.Petersburg, pp 131-154 (in Russian).

Leppänen J, Pitkänen H, Savchuk O, Basova S, Drabkova V, Gran V, Heiskanen AS, Koponen J, Shpaer I, Silina N (1997) Eutrophication and its effects in the Gulf of Finland In: Sarkkula (ed) Proceedings of the Final Seminar of the Gulf of Finland Year 1996, Helsinki, pp 31-49

Litvinchuk LF, Rivier IK, Panov VE (2001) Dynamics of abundance, structure of population and fecundity of Ponto-Caspian cladoceran, Cercopagis pengoi (Ostroumov, 1891) (Polyphemoidea, Cercopagidae) in the eastern Gulf of Finland, the Baltic Sea. Biology of Inland Waters 1, pp 57-62 (in Russian)

Lyakhin YI, Makarova SV, Maximov AA, Savchuk OP, Silina NI (1997) Ecological situation in the eastern Gulf of Finland in July 1996. In: Savchuk OP, Davidan IN (eds) Ecosystem Models. Assessment of the Contemporary State of the Gulf of Finland. Part 2. Gydrometeoizdat, St. Petersburg, pp 416-434 (in Russian)

MacIsaac HJ, Grigorovich IA, Hoyle JA, Yan ND, Panov VE (1999) Invasion of Lake Ontario by the Ponto-Caspian cladoceran predator Cercopagis pengoi. Can J Fish Aquat Sci 56, pp 1-5

Menshutkin VV (ed) (1997) The Neva Bay - Experience of Modeling. St.Petersburg, p 375 (in Russian)

Nikulina VN, Trifonova IS, Letanskaya GI, Pavlova OA (1999) Phytoplankton In: Rumyancev VA, Drabkova VG (eds) Gulf of Finland under Anthropogenic Impact, St.Petersburg, pp 108-126 (in Russian)

Ojaveer H, Lumberg A (1995) On the role of Cercopagis (Cercopagis) pengoi (Ostroumov) in Pärnu Bay and the NE part of the Gulf of Riga ecosystem. Proc Estonian Acad Sci Ecol 5, No1/2, pp 20-25

Orlova MI, Anokhina LE, Panov VE, Nekrasov AV, Klimentenok SN (1999a) Preliminary environmental state assessment for littoral zone in Resort District of St.Petersburg. Balt Float Univ Res Bull No 3, pp 37-42

Orlova MI, Panov VE, Krylov PI, Telesh IV, Khlebovich VV (1999b) Changes in plankton and benthic communities in the eastern Gulf of Finland, associated with biological invasions. Proc Zool Inst, 279, pp 305-325 (in Russian) 
Panov VE, Krylov PI, Telesh IV (1996) The Caspian predatory cladoceran Cercopagis pengoi invades the Gulf of Finland. Balt Float Univ Res Bull No 2, pp 80-81

Panov VE, Alimov AF, Balushkina EV, Golubkov SM (1997) Functional approach to the evaluation of eutrophication in the Neva Estuary. In: Sarkkula J (ed) Proceedings of the Final Seminar of the Gulf of Finland Year 1996, Helsinki, pp 203-213

Panov VE, Alimov AF, Balushkina EV, Golubkov SM, Nikulina VN, Telesh IV, Finogenova NP (1997) Monitoring of biodiversity of bottom and plankton communities in the Neva Estuary. In: Sokolov VE, Reshetnikov YS, Shatunovski MI (eds) Monitoring of Biodiversity. Moscow, pp 288-294 (in Russian)

Panov VE, Krylov PI, Telesh IV (1999) The St. Petersburg harbour profile. In: Gollasch S, Leppäkoski E (eds) Initial Risk Assessment of Alien Species in Nordic Coastal Waters, Nord 1999:8, Nordic Council of Ministers, Copenhagen, pp 225-244

Panov VE, Timm T, Timm H (2000) Current status of an introduced Baikalian amphipod Gmelinoides fasciatus Stebbing, in the littoral communities of Lake Peipsi. Proc. Estonian Acad. Sci. Biol. Ecol. 49, No 1, pp 71-80

Pitkänen H (1991) Nutrient dynamics and trophic conditions in the eastern Gulf of Finland: the regulatory role of the Neva Estuary. Aqua Fennica 21, No 2, pp 105-115

Pitkänen H, Tamminen T (1995) Nitrogen and phosphorus as production limiting factors in the estuarine waters of the eastern Gulf of Finland. Mar Ecol Prog Ser, 129, pp 283294

Reynoldson TB (1993) The development of ecosystem objectives for the Laurentian Great Lakes. Journal of Aquatic Ecosystem Health, 2, pp 81-85

Rumyantsev VA (1999) The Gulf of Finland - main problems of the first quarter of XXI century. In: Rumyancev VA, Drabkova VG (eds) Gulf of Finland under Anthropogenic Impact, St.Petersburg, pp 355-363 (in Russian)

Rybalko AE, Spiridonov MA (1999) Assessment of ecological situation in the system Lake Ladoga - Neva River - Gulf of Finland, based on results of bottom sediments investigation. In: Rumyancev VA, Drabkova VG (eds) Gulf of Finland under Anthropogenic Impact, St.Petersburg, pp 101-106 (in Russian)

Savchuk OP, Andreev OA, Sokolov AV, Chernyshova ES (1997) Modeling of biogeochemical cycling in the Gulf of Finland ecosystem. In: Savchuk OP, Davidan IN (eds) Ecosystem Models. Assessment of the Contemporary State of the Gulf of Finland. Part 1. Gydrometeoizdat, St. Petersburg, pp 47-64 (in Russian)

Shishkin BA, Nikulina VN, Maximov AA, Silina NI (1989) Basic Characteristics of the Biota in Upper Gulf of Finland and its Role in Water Quality Formation. Hydrometeoizdat, Leningrad, p 95 (in Russian)

Smirnova AI (1997) River discharge. In: Savchuk OP, Davidan IN (eds) Ecosystem Models. Assessment of the Contemporary State of the Gulf of Finland. Part 2. Gydrometeoizdat, St. Petersburg, pp 188-193 (in Russian)

Silina NI (1997) Zooplankton and its role in the biological processes. In: Savchuk OP and Davidan IN (eds) Ecosystem Models. Assessment of the Contemporary State of the Gulf of Finland. Part 2. Gydrometeoizdat, St. Petersburg, pp 365-375 (in Russian)

Sprules WG, Riessen HP, Jin EH (1990) Dynamics of the Bythotrephes invasion of the St. Lawrence Great Lakes. J Great Lakes Res 16, pp 346-351

Telesh IV, Nikulina VN (1997) Water quality classification based on plankton communities. In: Sarkkula J (ed) Proceedings of the Final Seminar of the Gulf of Finland Year 1996, Helsinki, pp 167-175 
Telesh IV, Alimov AF, Golubkov SM, Nikulina VN, Panov VE (1999) Response of aquatic communities to anthropogenic stress: a comparative study of the Neva Bay and the eastern Gulf of Finland. Hydrobiologia 393, pp 95-105

Telesh IV, Bolshagin PV, Panov VE (2001) Quantitative estimation of the impact of alien species Cercopagis pengoi (Crustacea: Onychopoda) on the structure and functioning of plankton community in the Gulf of Finland, Baltic Sea. Doklady Biol Sci 377 No 3, pp 427-429 (in Russian)

Umnov AA (1996) Application of mathematical models for the ecological state assessment of aquatic ecosystems (Neva Bay as example). In Alimov AF, Frolov AK (eds) Ecological State of Aquatic Ecosystems in the Neva River Basin, St.Petersburg, pp 155186 (in Russian)

Winberg GG, Gutelmakher BL (eds) (1987): The Neva Bay: Hydrobiological Investigations, Nauka, Leningrad, p 216 (in Russian) 